\title{
Detection of a new ilarvirus infecting wild radish in New Zealand
}

\author{
Z. Perez-Egusquiza • L. I. Ward • G. R. G. Clover
}

Received: 29 October 2013 / Accepted: 27 March 2014 / Published online: 18 September 2014

(C) Australasian Plant Pathology Society Inc. 2014

\begin{abstract}
A new ilarvirus was detected in wild radish in New Zealand. Numerous isometric particles (Ø $35 \mathrm{~nm})$ were seen by electron microscopy. Partial sequences for RNA1, RNA2 and RNA3 were obtained. Based on sequence data, the virus belongs to the Ilarviruses subgroup 1, which members normally cause diseases of economic importance in their hosts, however it is unknown if the virus contributed to the severe symptoms observed in the plant also infected with Turnip mosaic virus.
\end{abstract}

Keywords Ilarvirus subgroup $1 \cdot$ Raphanus raphanistrum . Brassicaceae · RT-PCR

Wild radish (Raphanus raphanistrum) is a flowering plant in the family Brassicaceae. It is sometimes claimed to be the ancestor of the edible radish, Raphanus sativus. Native to Asia, wild radish has been introduced into most parts of the world. It spreads rapidly and is regarded as a damaging invasive species in many countries.

In May 2009, a sample of wild radish showing severe symptoms of leaf deformation, vein clearing, and a mosaic of light and dark green colours on the leaves (Fig. 1) was collected from the Wellington region of New Zealand. Electron microscopy of a crude sap preparation showed numerous isometric $(\varnothing 35 \mathrm{~nm})$ and flexuous filamentous particles ( $\sim 800 \mathrm{~nm}$ long). Total RNA was extracted from the plant using an RNeasy Plant Mini Kit (Qiagen, Doncaster, Australia). The sample was tested by reverse transcription (RT)-PCR using different sets of generic primers for the

Z. Perez-Egusquiza $(\bowtie) \cdot$ L. I. Ward · G. R. G. Clover Plant Health and Environment Laboratory, Ministry for Primary Industries, P.O. Box 2095, Auckland 1140, New Zealand

e-mail: zoila.perez@mpi.govt.nz detection of ilarviruses (Untiveros et al. 2010) and potyviruses (Marie-Jeanne et al. 2000). An amplicon of the expected size from the potyvirus assay was directly sequenced and a BLASTn search showed $97 \%$ identity to Turnip mosaic virus (TuMV) (GenBank Accession No.AB252141). PCR products of the expected sizes were also obtained with the ilarvirus PCR assays targeting RNA1 and RNA2. A BLASTn search showed no more than $65 \%$ (RNA1) and $75 \%$ (RNA2) sequence identity with other members of the genus Ilarvirus, with members of Subgroup 1 (Tobacco streak virus group) being the closest match. Using available sequences of ilarviruses in subgroup 1 , walking primers were designed from conserved regions of RNAs 1, 2 and 3 and used to amplify more sequence from the wild radish ilarvirus. Amplicons of the expected sizes were obtained with most of the primers sets using RTPCR and were directly sequenced. All sequences obtained were assembled using Geneious 5.5 software (Biomatters Ltd, Auckland, New Zealand) and a total of 2,340 nt of RNA1, $970 \mathrm{nt}$ of RNA2 and 1,350 nt of RNA3 were obtained and deposited in the GenBank under the name of Raphanus latent virus (Accession Nos.JN107637 to JN107639). Analysis of the amino acid sequence from the wild radish ilarvirus RNA1 matched Blackberry chlorotic ringspot virus, Strawberry necrotic shock virus and Tobacco streak virus with $61 \%$ identity, followed by Bacopa chlorosis virus and Parietaria mottle virus with $60 \%$ and $58 \%$ identity respectively. The low genetic similarity with other members within the genus suggests that the wild radish ilarvirus is a different, previously undescribed species. Symptoms observed in the wild radish were similar to those previously described for TuMV (Tomlinson 1970). It is not known if the presence of this new ilarvirus enhanced the symptoms of TuMV in the plant or if the virus could produce distinct symptoms if present by itself. Most ilarviruses cause diseases of economic importance in 


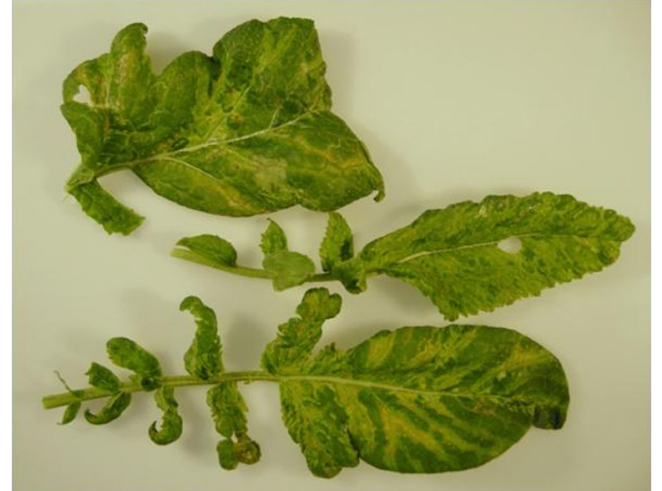

Fig. 1 Leaves of Raphanus raphanistrum infected with TuMV and the new Ilarvirus

their hosts. This new ilarvirus could potentially have an impact in brassica crops; however, its importance is currently unknown. Since this first identification, the virus has not been detected again, so the current distribution is also unknown.

\section{References}

Marie-Jeanne V, Ioos R, Peyre J, Alliot B, Signoret P (2000) Differentiation of poaceae potyviruses by reverse transcriptionpolymerase chain reaction and restriction analysis. J Phytopathol 148:141-151. doi:10.1046/j.1439-0434.2000.00473.x

Tomlinson JA (1970) Turnip mosaic virus. Descriptions of plant viruses. Association of applied biologists. http://www.dpvweb.net/dpv/ showdpv.php?dpvno=8. Accessed 30 October 2013

Untiveros M, Perez-Egusquiza Z, Clover G (2010) PCR assays for the detection of members of the genus Ilarvirus and family Bromoviridae. J Virol Methods 165:97-104. doi:10.1016/j.jviromet. 2010.01.011 